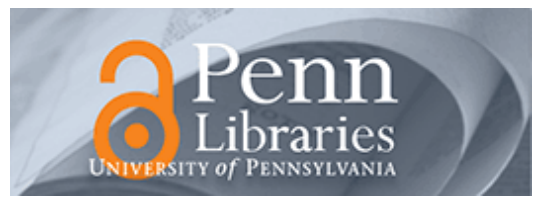

University of Pennsylvania

ScholarlyCommons

Management Papers

Wharton Faculty Research

$10-2014$

\title{
Estimating the Impact of Trade and Offshoring on American Workers Using the Current Population Surveys
}

Avraham Ebenstein

Ann E. Harrison

University of Pennsylvania

Margaret S. McMillan

Shannon Phillips

Follow this and additional works at: https://repository.upenn.edu/mgmt_papers

Part of the Business Administration, Management, and Operations Commons, and the Economics Commons

\section{Recommended Citation}

Ebenstein, A., Harrison, A. E., McMillan, M. S., \& Phillips, S. (2014). Estimating the Impact of Trade and Offshoring on American Workers Using the Current Population Surveys. The Review of Economics and Statistics, 96 (4), 581-595. http://dx.doi.org/10.1162/REST_a_00400

This paper is posted at ScholarlyCommons. https://repository.upenn.edu/mgmt_papers/104

For more information, please contact repository@pobox.upenn.edu. 


\title{
Estimating the Impact of Trade and Offshoring on American Workers Using the Current Population Surveys
}

\author{
Abstract \\ We link industry-level data on trade and offshoring with individual-level worker data from the Current \\ Population Surveys from 1984 to 2002. We find that occupational exposure to globalization is associated \\ with significant wage effects, while industry exposure has no significant impact. We present evidence that \\ globalization has put downward pressure on worker wages through the reallocation of workers away from \\ higher-wage manufacturing jobs into other sectors and other occupations. Using a panel of workers, we \\ find that occupation switching due to trade led to real wage losses of 12 to 17 percentage points.

\section{Disciplines} \\ Business Administration, Management, and Operations | Economics
}




\title{
The Review of Economics and Statistics
}

VOL. XCVI

OCTOBER 2014

Number 4

\section{ESTIMATING THE IMPACT OF TRADE AND OFFSHORING ON AMERICAN WORKERS USING THE CURRENT POPULATION SURVEYS}

\author{
Avraham Ebenstein, Ann Harrison, Margaret McMillan, and Shannon Phillips*
}

\begin{abstract}
We link industry-level data on trade and offshoring with individual-level worker data from the Current Population Surveys from 1984 to 2002. We find that occupational exposure to globalization is associated with significant wage effects, while industry exposure has no significant impact. We present evidence that globalization has put downward pressure on worker wages through the reallocation of workers away from higher-wage manufacturing jobs into other sectors and other occupations. Using a panel of workers, we find that occupation switching due to trade led to real wage losses of 12 to 17 percentage points.
\end{abstract}

\section{Introduction}

B ETWEEN 1983 and 2002, the U.S. economy experienced a boom in offshoring and a doubling of imports of manufactured goods from low-income countries. Over this same period, roughly 6 million jobs were lost in manufacturing, and income inequality increased sharply. These parallel developments led some critics of globalization to conclude that "good" manufacturing jobs had been shipped overseas, putting downward pressure on wages of middleclass American workers. Concern over these developments motivated the U.S. Congress to pass the American Jobs Creation Act of 2004. Yet the degree to which changes in the U.S. labor market are related to growth in international trade and offshoring is still the subject of heated debate.

The standard approach to identifying effects of import competition on wages is to use variation in the prices (or quantities) of imported goods across industries over time as an exogenous shock and examine the impact on industryspecific labor market outcomes. This approach has been used to measure the impact of globalization on industry wage differentials and the effects of sector-specific import competition on wages and employment. For example, Feenstra and Hanson (1999) use a two-step procedure, first iden-

Received for publication May 23, 2011. Revision accepted for publication April 8, 2013. Editor: Gordon Hanson.

* Ebenstein: Hebrew University of Jerusalem; Harrison: University of Pennsylvania and NBER; McMillan: Tufts University and NBER; Phillips: Boston College.

We thank the editor, two anonymous referees, Rajeev Dehejia, Gene Grossman, James Harrigan, and John MaLaren for helpful comments on earlier versions of the manuscript. We also thank seminar participants at the University of Maryland, the University of Virginia, and Yale University for helpful comments. Special thanks to David Autor, Robert Feestra, Wayne Gray, and Lawrence Edwards for providing data critical to our analysis. Excellent research assistance was provided by Catherine Almirall, Revital Bar, Joan Fang, and Michael Freedman.

A supplemental appendix is available online at http://www.mitpress journals.org/doi/suppl/10.1162/REST_a_00400. tifying the impact of outsourcing and high-technology investments on productivity and prices and then tracing through the impact of induced productivity and price changes on relative wages among production and nonproduction workers. Using data for the U.S. manufacturing sector between 1979 and 1990, they find that the real wages of production workers were probably unaffected by offshoring activities, while the real wages of nonproduction workers increased by 1 to 2 percentage points. Bernard, Jensen, and Schott (2006), in the first paper to distinguish between imports from high-income versus low-income countries, find that only low-income imports negatively affected firm exit, survival, and employment growth.

A key limitation of the previous literature on the labor market effects of globalization is that it typically focuses on changes within manufacturing. In this paper, we focus on potential wage impacts across occupations, both within manufacturing and across the broader economy. In a typical occupation, some workers are in tradable sectors (e.g., manufacturing), and others are in nontradable sectors (e.g., fast food services). To expand our analysis of wage outcomes due to globalization beyond manufacturing, we begin by defining the concept of occupational exposure to international trade or offshoring activities. ${ }^{1}$ Inasmuch as the demand for a particular worker's skill is affected by trade, those who are working in either the tradable or nontradable goods (or services) sector could be hurt by foreign competition. Also, if occupational tenure and experience is a more important determinant of wages than industry experience, then focusing on exposure at the industry level may understate the costs of globalization.

In order to examine this empirically, we link industrylevel data on trade and offshoring with individual-level worker data from the Current Population Surveys (CPS). We find a significant divergence between the impact of occupational exposure and industry exposure to globalization on wage outcomes. In particular, we find no significant negative effects of either international trade or offshoring on wages of all types of workers if we measure globalization at the industry level. When we focus on occupational exposure and include workers in both manufacturing and services, however, we find large and significant effects. Our

\footnotetext{
${ }^{1}$ We are greatly indebted to Gordon Hanson for suggesting this idea.
} 
analysis indicates that workers in routine occupations, such as those employed in blue-collar production occupations, have suffered the greatest losses from globalization. These results are consistent with recent empirical work demonstrating the importance of occupational tenure and downplaying the importance of tenure within a particular industry for a worker's wages (Kambourov \& Manovskii, 2009a, 2009b). ${ }^{2}$

We also explore how the impact of globalization has changed over time. A number of scholars have suggested that wage pressure from developing countries is likely to have increased during the 1990s. Feenstra (2008) singles out expanded competition from China as having exerted pressure on U.S. wages, and he is not alone in this view (see also Freeman, 1995, and Krugman, 2008). Empirical evidence for this conjecture is limited, however. ${ }^{3}$ We find that while the impact of trade and offshoring on U.S. wages through the mid-1990s was small in magnitude and insignificant, the effects became much larger in the second half of the 1990s. By the end of our sample period in 2002, we find significant and economically important effects of globalization on wages using our occupational exposure measure. Based on our study, it is likely that the impact of globalization on U.S. wages in since 2002 has increased further as more firms have engaged in offshoring to low-wage destinations. ${ }^{4}$

We examine the impact of globalization on U.S. workers by focusing attention on how they are affected by imports, exports, and offshoring to low- and high-income countries. Our results indicate that a $10 \%$ increase in occupational exposure to import competition is associated with nearly a $3.0 \%$ decline in real wages for workers who perform routine tasks among workers in our 1984 to 2002 sample and a 4.4\% decline for workers taken from 1997 to $2002 .{ }^{5}$ We also find substantial wage effects of offshoring to low-wage countries: a 10 percentage point increase in occupation-specific exposure to overseas employment in low-wage countries is associated with a $0.7 \%$ decline in real wages for workers performing routine tasks for our entire sample and a $2.0 \%$ decline for 1997 to 2002. For routine occupations with sig-

\footnotetext{
${ }^{2}$ Kambourov and Manovskii (2009a) find that "returns to occupational tenure are substantial." They also indicate that "when occupational experience is taken into account, tenure with an industry or employer has relatively little importance in accounting for the wage one receives. This finding is consistent with human capital being occupation specific." Their results imply that switching occupations will have a much greater impact on worker wages than switching industries.

${ }^{3}$ One important exception is Autor, Dorn, and Hanson (2012), who exploit differences in U.S. regional exposure to import competition from China to show significant effects on employment, unemployment, and wages from 1990 to 2007.

${ }^{4}$ Since the CPS changed its occupational coding scheme in 2003, we do not attempt analysis beyond 2002 in this paper. Our analysis of Bureau of Economic Analysis data indicates that offshoring to low-wage countries has increased markedly since 2002, with employment in low-income countries (e.g., China) exceeding that of high-wage countries.

${ }^{5}$ This finding is consistent with recent work highlighting the differential impact of offshoring by worker skill type. Hummels et al. (2011) use matched worker and firm data from Denmark and find that offshoring raises skilled worker wages but lowers unskilled worker wages, while exporting raises the wages of all types of workers.
}

nificant export activity, wages are positively linked to export growth. For these workers, a 10 percentage point increase in export share at the occupation level is associated with a 6.7 percentage point increase in wages over the sample period. For the end of the period (1997-2002), every percentage point increase in export shares for routine workers is associated with a percentage point increase in wages.

We also find that globalization has put downward pressure on worker wages through the reallocation of workers away from higher-paid manufacturing sectors toward other sectors and a shift of workers out of trade-vulnerable occupations. First, we find that domestic employment has declined in industries with expansion in low-income-country employment, consistent with evidence that multinational firms have shifted production overseas. ${ }^{6}$ Then, using a subset of the CPS data where we are able to match the same worker over time, we estimate a first-stage equation with the exposure of an occupation to trade as an instrument for whether a worker switched occupations. In the second stage, we find that occupation switching due to trade led to real wage losses of 12 to 17 percentage points between 1984 and $2002 .^{7}$ Any analysis of the wage effects of globalization that is restricted to manufacturing workers would miss the downward pressure on wages resulting from workers leaving manufacturing and entering the service sector. The associated distributional implications are potentially important, given historically large wage premiums paid to manufacturing (relative to service) workers in the United States (see figure 1 for a graphical exposition) and significant empirical evidence that industries compensate workers differently. ${ }^{8}$ It is also worth noting that our results are unlikely to be explained by the fact that weaker workers are more likely to switch occupations (Trefler \& Lui, 2011). When we control for unobserved differences in worker quality among those who switch occupations, we continue to find suggestive results that the wage declines associated with globalization are due to worker's switching occupations.

An important limitation of our study (and other papers in this literature) is that we are unable to fully separate the

\footnotetext{
${ }^{6}$ Our results corroborate results on employment declines within manufacturing by Harrison and McMillan (2011), who use firm-level data on multinational manufacturing firms, but they stand in contrast to Desai, Foley, and Hines (2009), who do not distinguish between high-wage and low-wage affiliate employment and find that offshoring is unambiguously positive for U.S. employment.

${ }^{7}$ Other scholarship has documented the cost of trade-induced shifts in employment. Menezes-Filho and Muendler (2011) use a Brazilian trade reform to document significant short-run costs to workers and sticky intersectoral labor reallocation. Artuc, Chaudhuri, and McLaren (2010) develop a theoretical model showing that adjustment costs for workers are likely to be significant and can explain why there is likely to be sluggish reallocation and short-term negative wage effects on workers under trade liberalization. Cosar (2011) also explores sluggish labor market adjustments by developing a two-sector small, open economy, overlapping-generations model that is calibrated to Brazilian data. The paper finds that human capital is a much bigger barrier to labor mobility than search frictions.

${ }^{8}$ See, for example, Katz and Summers (1989) and Krueger and Summers (1988).
} 

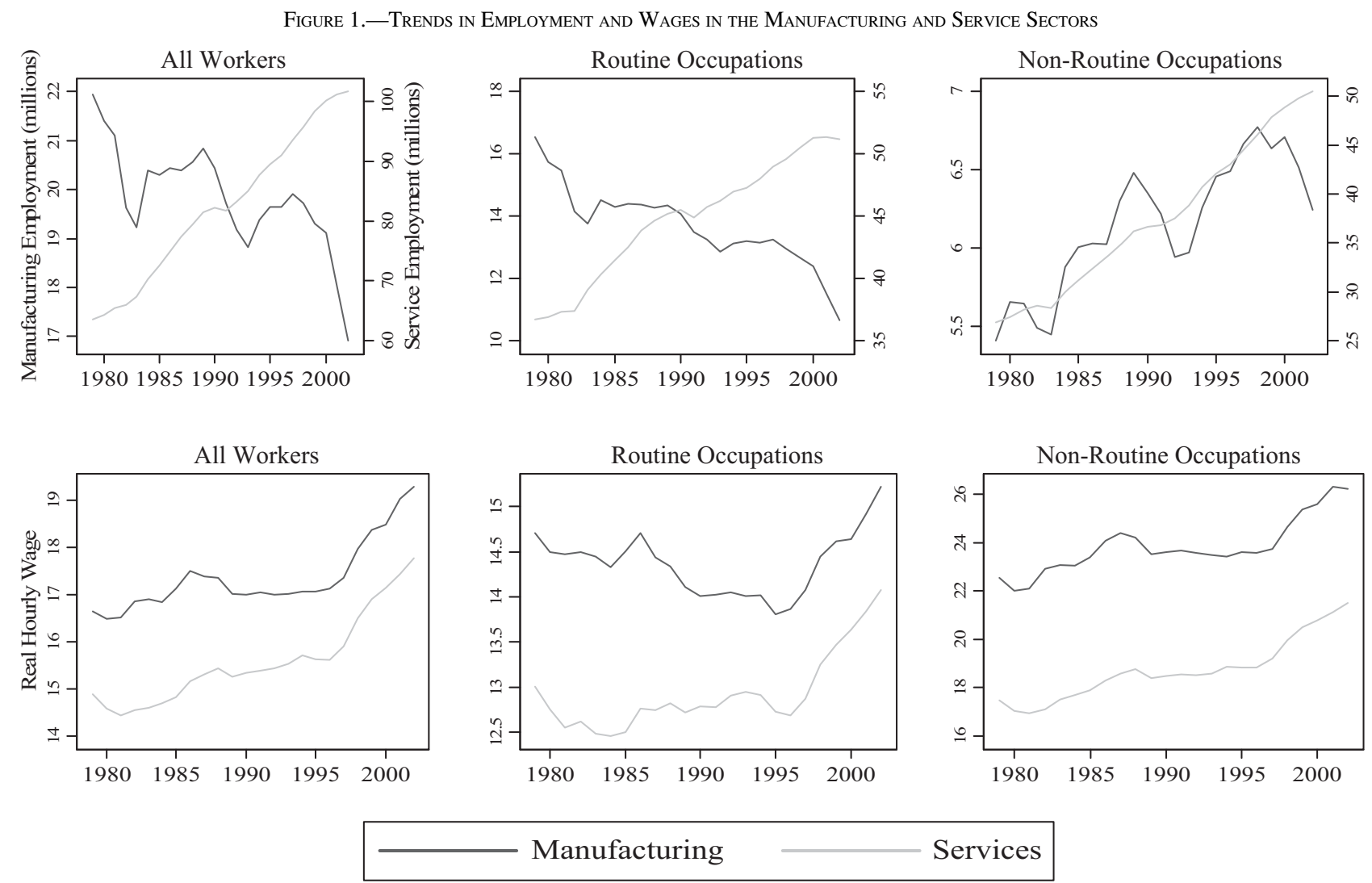

Employment and wage calculations are based on the Current Population Survey Merged Outgoing Rotation Groups (MORG). Sample includes all part-time and full-time workers. Wages are in 2005 dollars. The definition of routine workers is based on occupational task content. Details are available in the data appendix.

impact of trade and offshoring from other changes in the labor market. Two primary identification challenges exist. First, it may be that trade and offshoring are the result of changes in the domestic labor market. For example, if firms choose to move operations offshore in response to changes in the domestic labor market (e.g., unions), this reverse causality would invalidate the causal interpretation of our results. Second, it may be that technological change is correlated with trade in a manner preventing causal interpretation of our coefficient estimates. For example, if more routine tasks are more easily performed overseas or automated, we will be unable to accurately characterize the counterfactual of how wages would have evolved in the absence of globalization. Insofar as some workers face competitive pressure from low-wage workers in foreign countries and automation, it will be difficult to separately identify the impact of either exposure. We attempt to address these concerns in several ways. First, by combining industry-level trade or offshoring data with individual-level information on wages and worker characteristics, we hope to sidestep the issue of reverse causality since it is difficult for one worker to affect aggregate trade outcomes. Second, we pay considerable attention to capturing technological change across industries that could influence both worker wages and globalization outcomes. We include annual measures of total factor productivity, capital accumulation, the price of investment goods by industry, and computer use rates by industry and occupation, which represents our best attempt to account for technical change that could potentially affect workers directly. Third, we explore the robustness of our results to instrumental variable estimation, where we exploit factors that should affect the tradability of certain goods, or the desirability of certain offshore locations (results available in online appendixes). These instruments may themselves be endogenous, however. Consequently, we focus our attention mainly on results that rely on fixed effects by industry and occupation and the available control variables to measure the impact of globalization on workers. The focus of this paper is on the importance of occupation versus industry-level measures of exposure to globalization, and that focus is important regardless of identification issues, which will continue to remain a challenge. In the absence of a "clean" natural experiment or a fully compelling instrument for the tradability of certain occupations, our results must be interpreted with appropriate caution. ${ }^{9}$

\footnotetext{
${ }^{9}$ In a recent paper, Jensen and Kletzer (2005) attempt to measure the tradability of service sector goods using an approach that considers the spatial concentration of service industries and occupations. They posit that more spatially concentrated industries or occupations are more tradable and find evidence consistent with this hypothesis in U.S. data. We chose not to pursue this strategy, as geographical concentration may reflect other factors, such as state-specific regulations that lead to clustering of certain industries or occupations.
} 
The paper is organized as follows. Section II describes our data; documents broad trends in trade, offshoring, wages, and employment; and presents the empirical specification. Section III presents our main empirical findings regarding the impact of offshoring and trade on domestic wages and employment at the occupation versus the industry level. Section IV concludes.

\section{Data Description, Empirical Strategy, and Trends}

\section{A. Data Description}

Our sample of U.S. workers is taken from the Current Population Survey Merged Outgoing Rotation Groups for 1983 to 2002, which provides data for over 3.4 million workers who are assigned a consistent classification for their industry and occupation during the period. ${ }^{10}$ Offshore activity in each industry is measured by the total employment of foreign affiliates among multinational U.S. firms, separated into high- and low-income affiliate locations, as collected by the Bureau of Economic Analysis (BEA). ${ }^{11}$ Our data on import penetration and export shares are taken from Bernard at al. (2006), which we recalculated and updated through 2002. Since relative price series for imports and exports are incomplete, we substitute for prices by using the share of exports in production and import penetration at the four-digit SIC 1987 level. ${ }^{12}$ We control for productivity changes that could also affect labor demand as well as wages using the NBER's calculations of total factor productivity provided by Wayne Gray. This data source also provides us with measures of the prices of investment goods, capital-to-labor ratios, and the real price of shipments by industry and year. ${ }^{13}$ These are included in our main specifications to control for technological change that could also affect wage rates. Finally, we match our workers to information on computer use rates by industry and occupation from CPS computer supplements conducted during our sample period $(1984,1989,1993,1997,2000)$. Using

\footnotetext{
${ }^{10}$ We express our gratitude to David Autor for providing us with concordances that provided a consistent coding scheme of industries and occupations for the period. The CPS occupation and industry codes were reclassified in 2003 to correspond to the North American Industrial Classification System, which made it difficult to compare data before and after the change. We begin with 1984 because occupation codes for the 19791981 period are not consistent with the classification for later years, and we use lags in our empirical specification that lead us to drop 1983.

${ }^{11}$ The BEA sample of multinational firms accounted for $80 \%$ of total output in manufacturing in 1980, suggesting that the coverage is fairly extensive. However, using these data, we are unable to distinguish between imports from affiliates (arm's-length trade between firms) and imports from nonaffiliates.

${ }^{12}$ Results using prices instead of quantities are available in the online appendix. The results are qualitatively similar to our main results using quantities.

${ }_{13}$ These data were aggregated from the four-digit to three-digit SIC level using the employment distribution in 1979. The three-digit SIC level was converted to our industry classification scheme using a concordance provided by David Autor that was a census-based scheme that consistently defined industries for our sample period. A similar method was used to match CPS workers to the trade data.
}

the available surveys, we interpolate and extrapolate computer use rates for the entire window. ${ }^{14}$ Summary statistics for the individual worker sample matched to our offshoring, trade, technology, and price data are available in table A1.

We use Autor et al.'s (2003) distinction between routine and nonroutine tasks to allow us to separately identify the impact of different measures of globalization across different types of workers. To the extent that routine tasks are more easily offshored or replaced with imports, we would expect globalization to have a larger impact on workers performing these types of tasks. Autor et al. (2003) describe routine jobs as "tasks that can be expressed using procedural or 'rules-based' logic, that is, codified in a fully specified sequence of logical programming commands ('IfThen-Do' statements) that designate unambiguously what actions the machine will perform and in what sequence at each contingency to achieve the desired result." While they use routineness to designate which jobs can be easily performed by computers, we would argue that routine jobs are also more readily codified, communicated, and consequently transferred overseas. Examples of these jobs include attaching hands to faces of watches, sewing fasteners and decorative trimming to articles, and services tasks that we think of as offshorable, such as answering telephones.

Following Autor et al. (2003), we aggregate five measures of the routineness of tasks into a single index for each occupation $k$. Two indicators, Routine Manual and Routine Cognitive, measure the routineness of tasks by occupation in each of these dimensions. These range from 1 for tasks that are not routine to 10 for tasks that are fully routine. The three other measures are (1) Direction, Control, and Planning of Activities (DCP), which measures non routine cognitive tasks; (2) Eye, Foot, and Hand coordination (EFH) activities, which require nonroutine manual task completion; and (3) the Math indicator, which measures the quantitative or analytical reasoning skills required. The index of routineness by worker education level, industry, and year is given by:

$$
\begin{aligned}
& \text { Routine }_{k} \\
& =\frac{\text { Routine Cognitive }_{k}+\text { Routine Manual }_{k}}{\text { Routine Cognitive }_{k}+\text { Routine Manual }_{k}+\text { DCP }_{k}+\text { EFH }_{k}+\text { Math }_{k}} .
\end{aligned}
$$

The index ranges from 0 to $1 .^{15}$ The last three terms, $D C P, E F H$, and Math, refer to cognitive tasks that are higher order in their complexity and presumably are asso-

\footnotetext{
${ }^{14}$ These data were also provided by David Autor and are used in Autor et al. (1998).

${ }^{15}$ See Autor et al. (2003) for a thorough description of these variables. Our calculation of routine is the sum of routine manual tasks (Finger Dexterity) and routine nonmanual (Set Limits, Tolerances, or Standards), as a share of those tasks and nonroutine manual (Eye, Hand, Foot), nonroutine analytic (General Educational Development, Mathematics), and nonroutine interactive (Direction, Control, and Planning) tasks. More details on this classification scheme are available in the online appendix.
} 
ciated with larger costs of performing outside a firm's central location.

\section{B. Empirical Strategy}

Our empirical strategy is to regress log wages of worker $i$ in industry $j$ in period $t\left(W_{i j t}\right)$ on lagged measures of exposure to offshoring and international trade $\left(G_{i j t-1}\right)$ using annual data from 1983 to 2002 , first at the industry level and subsequently at the occupation level, which we will define below. This paper examines the impact of globalization (i.e., offshoring and trade) on wages and the domestic labor market response to offshoring and trade in the short run. After controlling for all observables such as education, age, sex, ethnicity, and experience, workers in a frictionless world could costlessly move from one industry or occupation to another. We test this hypothesis and find that barriers exist at the occupation but not at the industry level.

We use lagged measures of exposure to offshoring and trade for two reasons. First, since offshoring requires time to implement, and wage adjustment is not instantaneous, it is unlikely that the causal effect of offshoring on wages will play out within a single calendar year. Second, within a given year, offshoring, trade exposure, and wages are likely to be affected by simultaneous shocks. We use four measures of exposure to offshoring and international trade: offshoring to low-income affiliate locations, offshoring to high-income affiliate locations, export shares, and import penetration. To allow for the possibility that offshoring to low-income locations might have different effects from offshoring to high-income locations, we include as separate regressors the $\log$ of employment in sector $j$ by U.S.-based multinationals in low- and high-income countries.

There are three additional challenges to identifying the causal effect of globalization on wages. First, the industries that are most likely to globalize may also be those with lower wages or greater volatility. We address this concern by including industry fixed effects $\left(I_{j}\right)$ in our specification. Second, globalization and wages may be jointly affected by common time-varying shocks, such as the business cycle and exchange rate fluctuations. We control for these by including time fixed effects $\left(d_{t}\right)$. Third, we control for timevarying shocks at the industry level that could be confounded with changes in globalization by adding a number of controls. TFP ${ }_{j t-1}$ captures changes in productivity by industry and year that could affect demand for labor. ${ }^{16} \mathrm{We}$ also attempt to capture productivity changes including two (arguably) exogenous measures, the price of investment goods and computer use rates. The price of investment goods $P I N V_{j t-1}$ captures in part the role of falling computer prices and the potential impact of labor-saving technology on labor market outcomes. We also control for industry factor intensity (lagged capital to labor ratio $K L R A T I O_{j t-1}$ )

\footnotetext{
${ }^{16}$ Since total factor productivity is a function of wages, we estimate our equations with and without total factor productivity. The results are similar with and without controlling for TFP.
}

and computer use rates by industry and year $\left(C O M P_{j t}\right)$ to account for contemporaneous changes in an industry's wage rate based on the ability to substitute for labor with computers. ${ }^{17}$ Finally, we control for individual characteristics including age, sex, race, experience, education, and location $\left(Z_{i j t}\right)$ :

$$
\begin{aligned}
W_{i j t}= & \beta_{0} Z_{i j t}+\beta_{1} G_{j t-1}+\beta_{2} \text { TFP }_{j t-1}+\beta_{3} \text { PINV }_{j t-1} \\
& +\beta_{4} \text { KLRATIO }_{j t-1}+\beta_{5} \text { COMP }_{j t} \\
& +\beta_{6} d_{t}+\beta_{7} I_{j}+\varepsilon_{i j t} .
\end{aligned}
$$

To examine the relationship between wages and globalization at the occupation level, we retain the same setup as in equation (1a) but modify the $G$ vector to create a measure of occupational exposure to offshoring or trade. Each variable in the $G$ vector was created from a merged data set of BEA offshore employment data, trade data, and CPS monthly outgoing rotation group individual-level data, by industry and year. We calculate for each occupation its exposure to trade using the distribution of workers employed in this occupation across industries in 1983. For each occupation $k$ and industry $j$, we have $\alpha_{k j 83}=\frac{L_{k j 83}}{L_{k 83}}$, where $L_{k j 83}$ is the total number of workers in occupation $k$ and industry $j$ in 1983 and $L_{k 83}$ is the total number of workers across all industries in occupation $k$. We then calculate occupationspecific import penetration in year $t$ for occupation $k$ as

$$
\sum_{j=1}^{J} \alpha_{k j 83} I M P_{j t},
$$

where $\mathrm{IMP}_{j t}$ is the measure of import penetration for goods in industry $j$ in year $t$. We continue to control for technological changes by industry and set these technological changes equal to unity for workers outside manufacturing. ${ }^{18}$

This leads to a specification of the form:

$$
\begin{aligned}
W_{i j k t}= & \beta_{0} Z_{i j k t}+\beta_{1} G_{k t-1}+\beta_{2} \text { TFP }_{j t-1}+\beta_{3} P_{I N V_{j t-1}} \\
& +\beta_{4} \text { KLRATIO }_{j t-1}+\beta_{5} \text { COMP }_{k t}+\beta_{6} d_{t} \\
& +\beta_{7} I_{j}+\beta_{8} \text { Occupation }_{k}+\varepsilon_{i j k t},
\end{aligned}
$$

where $k$ indexes the worker's occupation, and workers within the same $k$ occupation may be in different $j$ industries. ${ }^{19}$ Our $G$ vector is now an occupation-specific measure for each worker, and we have added occupation fixed

\footnotetext{
${ }^{17}$ Our results are similar if we control for computer use rates in the previous year.

${ }^{18}$ An alternative approach would be to create occupation-specific measures of each of our control variables. In the online appendix, we estimate models with occupational-specific measures of TFP, the price of investment goods, and the capital-to-labor ratio. The results are qualitatively similar to the results presented in the main text. These are presented in table A9.

${ }^{19}$ For workers outside manufacturing, the control variables for TFP, $P I I N V$, and REALSHIP are not available and are therefore assumed constant in our main specifications.
} 
effects to absorb variation specific to time-invariant features of occupations. Note that we also control for variation in computer use rates by occupation and year, which is meant to account for wage changes driven by the ability of some occupations to benefit from computer technology (Autor et al., 1998). We will estimate this specification for all occupations separately by the degree of how routine the tasks are within a given occupation and for samples of workers who switch occupations. One important implicit assumption in our approach is that barriers to changing occupations are similar across routine and nonroutine occupations. Kambourov and Manovskii (2008) show this to be the case. They also decompose occupation switching across routine and nonroutine occupations and show that between 1968 and 1997, workers were not able to escape routine occupations by switching into nonroutine ones.

\section{Trends in Offshoring, Trade, Employment, and Wages}

In this section, we outline broad trends in the data for employment, wages, and the relationship between wages and measures of globalization. In figure 1, we compare the trends in employment and wages in the manufacturing sector alongside the same trends in the service sector between 1979 and 2002. We present these trends separately for workers performing routine and nonroutine tasks. Total manufacturing employment (using the CPS employment numbers) fell from 22 to 17 million from 1979 to 2002 , with rapid declines at the beginning of the early 1980s and in the late 1990s. Within manufacturing, the labor force has become increasingly high skilled, with a large decline of roughly 6 million in the number of workers in routine occupations and a modest increase of roughly 1 million in the number of workers performing nonroutine occupations.

In contrast, demand for both types of workers continued to grow in the service sector, and many of the displaced routine manufacturing workers may have found employment in the service sector. These trends have important implications for the U.S. wage distribution. As shown at the bottom of figure 1, where we report the real hourly wage among CPS workers, manufacturing workers enjoyed a large wage premium during the entire period among both routine and nonroutine workers. Insofar as manufacturing provided an opportunity to earn high relative wages, even for low-skill workers, its decline might also have played a role in increasing U.S. income inequality during the period. ${ }^{20}$

\footnotetext{
${ }^{20}$ See Autor, Katz, and Kearney (2008) for a review of these trends. It is worth noting that while the trends in figure 1 are informative, they do not control for other factors that affect income, such as sex, age, and experience. We redid the trends in wages by educational attainment using wage residuals. These wage residuals were computed using Lemieux's (2006) approach for each educational category separately. We also added industry dummies to control for interindustry wage differentials. The wage residuals show similar trends, with falling wage premiums for less educated workers and rising wage premium for more educated workers. Similar results are observed for wage premiums when workers are stratified by the routineness of occupation. Results are available from the authors on request.
}

Figure 2.-TRends in Domestic and Affiliate Employment among Multinational Firms

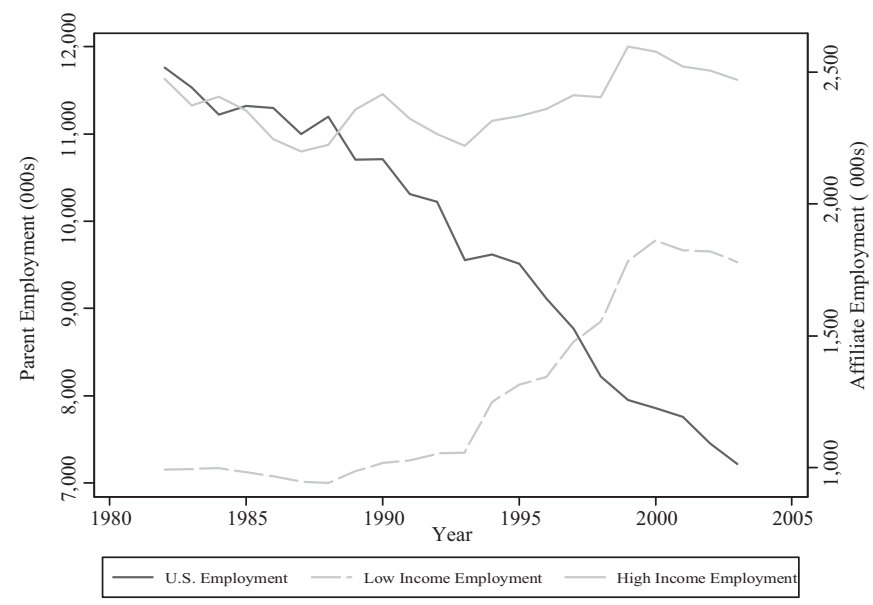

Authors' calculations based on the most comprehensive available data, and based on firm-level surveys on U.S. direct investment abroad, collected each year by the Bureau of Economic Analysis of the U.S. Department of Commerce. Using these data, we compute the number of employees hired abroad by country and year and then aggregate employment by low (high) income country according to World Bank income classifications.

The three panels displaying wage trends exhibit significant differences during the sample period. Real wages grew in the 1980s, fell or stagnated in the 1990s, and then begin increasing around 1995 to 1996 . Over the entire period, the gap between manufacturing and service wages narrowed, particularly from the mid-1990s onward. These different trends are one factor that leads us to break our samples into different time periods. We turn now to an examination of how offshoring and trade may be related to these employment and wage trends within manufacturing and in the overall economy.

As shown in figure 2, foreign affiliate employment in low-income countries by U.S.-based multinationals nearly doubled over the entire sample period, while affiliate employment in high-income countries remained roughly constant. The increase in developing country activity has been accompanied by a reduction in the U.S. workforce for these parents from almost 12 million workers in 1982 to 7 million workers in 2002.

In figure 3, we report changes in the distribution of occupation wage residuals across the 476 occupations in the CPS. Each point in the figure represents the occupationspecific wage premium in 1983 and 2002. The wage premium was calculated by taking the residual in a regression of real log wages on education category dummies; experience category dummies; an interaction of education and experience; and controls for sex, race, year, and state. ${ }^{21}$ These premiums were then collapsed into one term for each occupation and year. In order to compare the occupational wage residual changes by their potential exposure to offshoring, we stratify occupations by whether they are above the median occupation in terms of routine task content. As

\footnotetext{
${ }^{21}$ The data sets are made available online for replication at the Dataverse Network Project.
} 
Figure 3.-Occupational Wage Premiums in 1983 and 2002 among Routine and Nonroutine Occupations
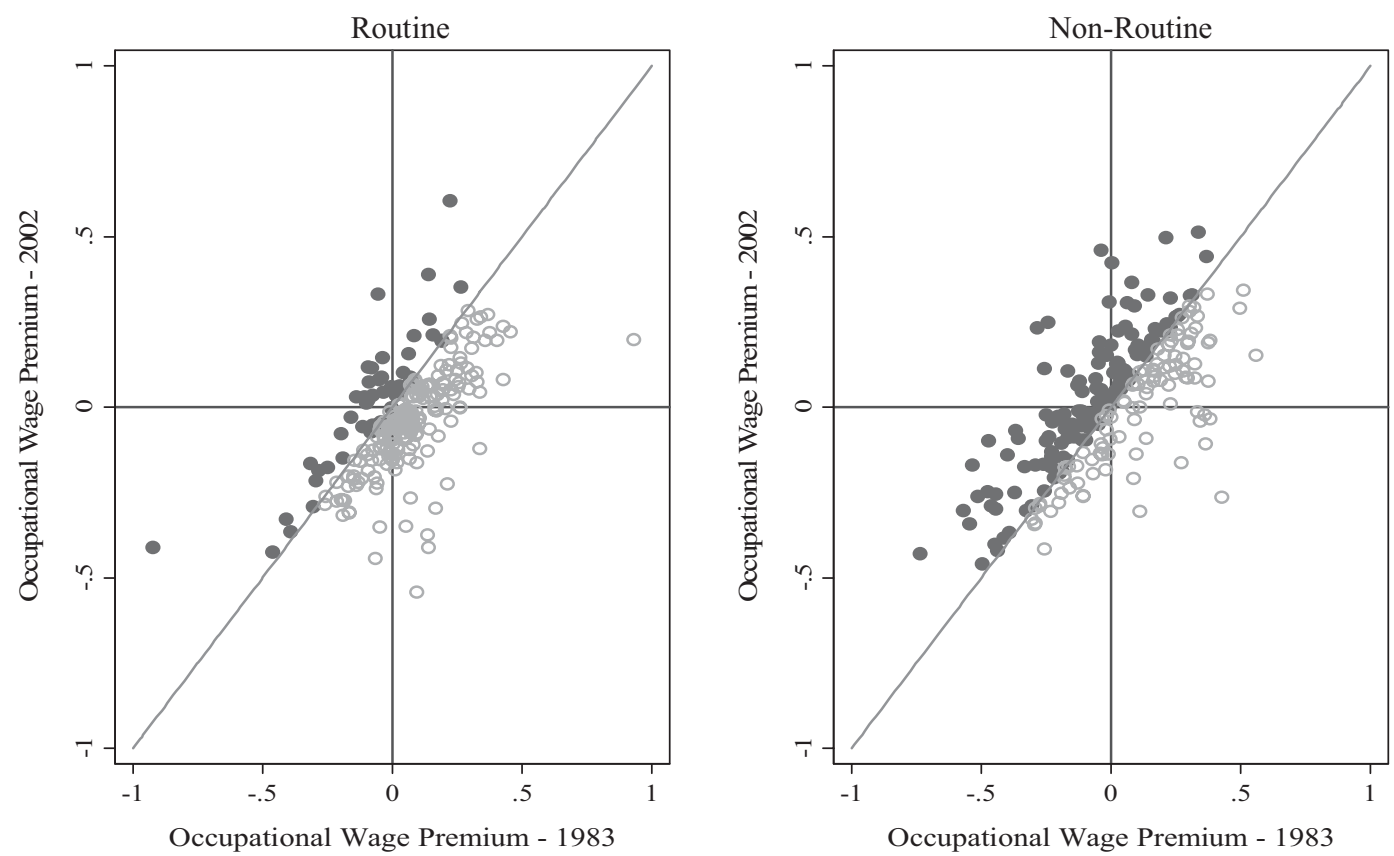

Wage premiums are calculated by a standard Mincerian regression of the log wage on education, experience, age, sex, race, year fixed efffects, and state fixed effects among all workers in the CPS MORG between in 1983 and 2002. Each point on the plot is a separate occupation identified in the CPS $(N=464)$. The occupations are considered routine if the share of tasks that is routine is greater than the median occupation. Occupations with higher wage premiums in 2002 than in 1983 are shaded.

Table 1.-OLS Estimates of Change in Offshoring and Import Penetration Given Industry Skill Composition in 1983

\begin{tabular}{|c|c|c|c|c|c|c|}
\hline & \multicolumn{4}{|c|}{$\begin{array}{c}\text { Dependent Variable: Log Difference in Employment } \\
\text { Offshored (1983-2002) }\end{array}$} & \multirow{2}{*}{\multicolumn{2}{|c|}{$\begin{array}{l}\text { Dependent Variable: } \\
\text { Import Penetration } \\
\text { Difference } \\
(1983-2002)\end{array}$}} \\
\hline & \multicolumn{2}{|c|}{$\begin{array}{l}\text { Low-Income } \\
\text { Countries } \\
\end{array}$} & \multicolumn{2}{|c|}{$\begin{array}{c}\text { High-Income } \\
\text { Countries }\end{array}$} & & \\
\hline & (1) & (2) & (3) & (4) & $(5)$ & (6) \\
\hline Industry share of routine jobs, 1983 & $\begin{array}{l}5.132 * * \\
(2.40)\end{array}$ & $\begin{array}{l}5.501 * * \\
(2.59)\end{array}$ & $\begin{array}{c}-0.980 \\
(2.03)\end{array}$ & $\begin{array}{c}-0.053 \\
(2.26)\end{array}$ & $\begin{array}{l}1.217 * * * \\
(0.34)\end{array}$ & $\begin{array}{l}1.237 * * * \\
(0.33)\end{array}$ \\
\hline Difference in log of price of investment & & -0.262 & & $\begin{array}{r}0.234 \\
(0.40)\end{array}$ & & -0.079 \\
\hline Difference in total factor productivity & & 0.084 & & $\begin{array}{c}(0.40) \\
-0.056\end{array}$ & & $0.0242 * *$ \\
\hline level between 1983 and 2002 & & $(0.07)$ & & $(0.06)$ & & $(0.01)$ \\
\hline Difference in capital to labor ratio between & & -0.230 & & -1.218 & & -0.249 \\
\hline 1983 and 2002 & & $(1.21)$ & & $(1.06)$ & & $(0.16)$ \\
\hline Difference in computer use rates between & & 0.441 & & -0.391 & & 0.028 \\
\hline 1983 and 2002 & & $(0.68)$ & & $(0.59)$ & & $(0.09)$ \\
\hline Number of observations & 66 & 59 & 66 & 59 & 66 & 61 \\
\hline$R^{2}$ & 0.07 & 0.12 & 0.00 & 0.07 & 0.17 & 0.35 \\
\hline
\end{tabular}

shown in figure 3, over the sample period, routine occupations were more likely to experience declines in wage premiums, possibly because these tasks can be performed overseas at lower cost. Of 240 routine occupations, 187 experienced wage premium declines and only 53 had increases in their wage premium. In contrast, among 236 nonroutine occupations, 134 experienced increases and only 102 experienced declines.

Before estimating equations $1 \mathrm{a}$ and $1 \mathrm{~b}$, in table 1 we provide a descriptive regression that is consistent with the results presented in figure 3 . In particular, table 1 shows that an industry's share of routine jobs in 1983 is a good indica- tor of subsequent offshoring to low-income locations and increasing import penetration. The dependent variables are the log difference between 1983 and 2002 in employment offshored to low-income countries (in columns 1 and 2) or high-income countries (in columns 3 and 4) and the change in import penetration (in columns 5 and 6). As shown in column 1, an industry's share of routine jobs in 1983 is a significant predictor of the subsequent increase in employment offshored to low-income countries, explaining roughly $7 \%$ of the variation across industries as a single regressor. We estimate that industries with 1 percentage point more routine jobs in 1983 experienced a $5.1 \%$ increase in offshore 
Table 2.-OLS Estimates of Wage Determinants Using Occupational versus Industry Exposure to OfFshoring and Trade, $1984-2002$ Dependent Variable: Log Wage

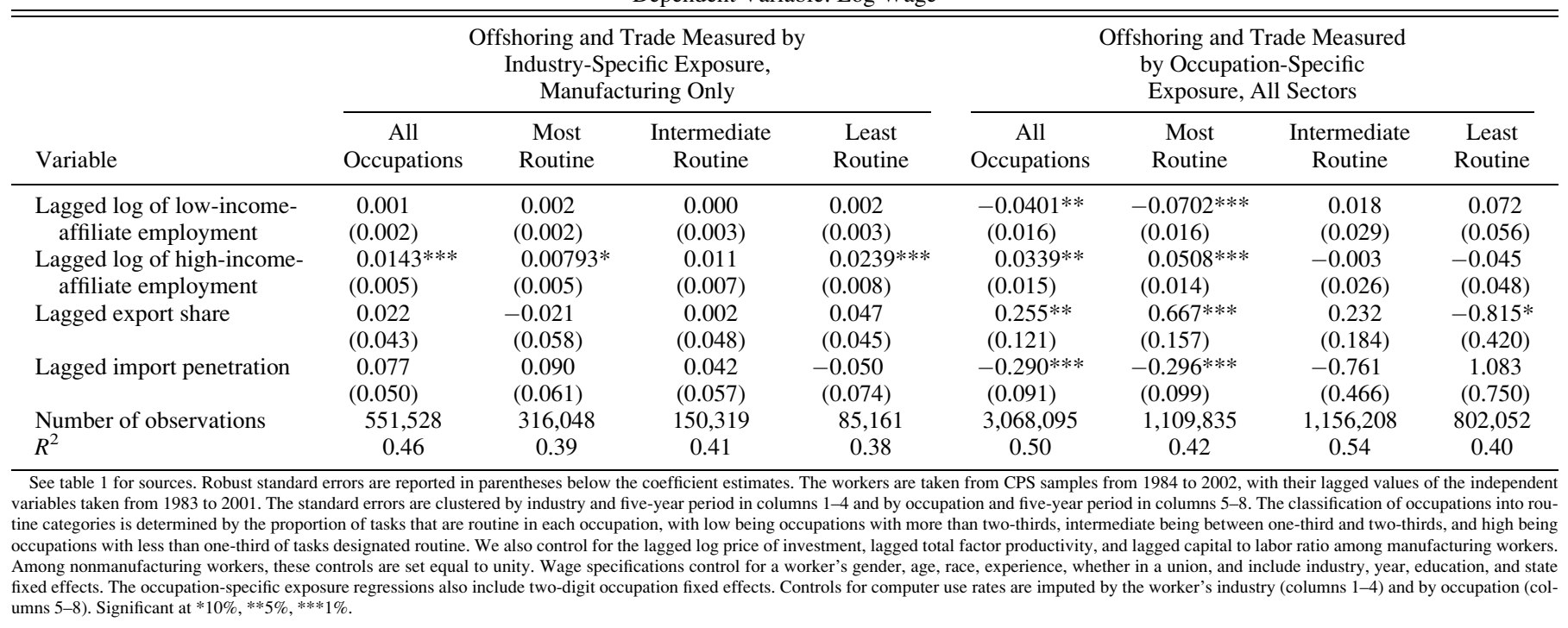

employment to low-income countries by 2002, and this result is statistically significant at the 5\% level. However, in column 3 , there is no significant relationship with offshoring to high-income countries. The significant relationship between an industry's share of routine jobs in 1983 and subsequent offshoring to low-income countries, which stands in contrast to high-income-country offshoring, is one reason to maintain the distinction between offshoring to high- and low-income countries in the subsequent analysis.

Column 5 shows that the industry share of routine jobs in 1983 is also a significant predictor of future increases in import penetration. We find a 1.2 percentage point increase in our import penetration measure among industries with 1 percentage point more routine jobs, suggesting that industries with more routine jobs have also faced greater import competition. In columns 2, 4, and 6, we include a range of additional predictors and continue to find similar effects for the industry share of routine jobs. Our control variables, which include industry averages of the price of investment goods, total factor productivity, capital-to-labor ratios, and computer use rates, do not qualitatively affect the results.

In the remainder of the paper, we continue to make a distinction between high- and low-income offshore locations and to differentiate workers by the routine content of their jobs. The patterns in the figures and table 1 indicate rising trade and offshoring to low-income countries in industries with workers whose jobs are characterized by a high routine content.

\section{Offshoring, Trade, and the Impact on Domestic Workers}

\section{A. Wage Impacts of Offshoring and Trade at the Industry versus Occupation Level}

In table 2, we present our main results showing how the impact of offshoring and trade are quite different when using industry versus occupation measures of exposure. In the first four columns, we present our estimates for equation (1a), which defines exposure to trade or offshoring at the industry level. In the last four columns, we redo the analysis using our occupation exposure measure, as outlined in equation (1b). We also present the main results where we stratify the workers based on the routine content of the worker's occupation, since we anticipate that routine tasks are more easily monitored offshore than more complex tasks, and so domestic workers performing these tasks may be more affected by offshoring and trade (Grossman \& Rossi-Hansberg 2008). Note that the standard errors are clustered by industry and five-year period in columns 1 through 4 and by occupation and five-year period in the last four columns. Industry regressions include industry fixed effects, and occupation regressions include occupation as well as industry fixed effects.

Columns 1 through 4 of table 2 identify the impact on wages of workers in industries that were more exposed to international trade or offshoring during the 1984-2002 period. ${ }^{22}$ In these four columns, only workers within the manufacturing sector are included in the estimation. The results suggest a very limited role for offshoring or trade in explaining $\log$ wages. There is no statistically significant relationship between low-income-affiliate employment, lagged export share, or lagged import penetration and industry-level wages; indeed, the point estimates are close to 0 . There is a positive and statistically significant relationship between high-income-affiliate employment and domestic wages, although the magnitude is not large: the point estimate suggests that a $1 \%$ increase in affiliate employment in high-

\footnotetext{
${ }^{22}$ Note that we exclude 1983 for consistency with our occupation results, which can only be estimated from 1984 to 2002, since occupation was coded consistently only from 1983 and on, and we are using lagged measures of our independent variables.
} 
Table 3.-OLS Estimates of Wage Determinants Using Occupational Exposure to Offshoring and Trade among Subsamples of CPS Workers, 1984-2002 Dependent Variable: Log Wage

\begin{tabular}{|c|c|c|c|c|c|c|}
\hline Specification & $\begin{array}{l}\text { Lagged Log of } \\
\text { Low-Income } \\
\text { Affiliate }\end{array}$ & $\begin{array}{l}\text { Lagged Log of } \\
\text { High-Income } \\
\text { Affiliate }\end{array}$ & $\begin{array}{l}\text { Lagged } \\
\text { Export } \\
\text { Share }\end{array}$ & $\begin{array}{c}\text { Lagged } \\
\text { Import } \\
\text { Penetration }\end{array}$ & Observations & $R^{2}$ \\
\hline 1984-1991 & $\begin{array}{c}0.003 \\
(0.012)\end{array}$ & $\begin{array}{c}-0.005 \\
(0.01)\end{array}$ & $\begin{array}{l}0.06 \\
(0.109)\end{array}$ & $\begin{array}{c}-0.215^{* * * *} \\
(0.067)\end{array}$ & $1,390,331$ & 0.52 \\
\hline 1992-2002 & $\begin{array}{l}-0.0558^{* * * *} \\
(0.013)\end{array}$ & $\begin{array}{l}0.0449 * * * \\
(0.011)\end{array}$ & $\begin{array}{l}0.490 \text { *** } \\
(0.081)\end{array}$ & $\begin{array}{c}-0.321 * * * \\
(0.062)\end{array}$ & $1,677,763$ & 0.49 \\
\hline 1984-1996 & $\begin{array}{c}-0.015 \\
\quad(0.009)\end{array}$ & $\begin{array}{c}0.0102 \\
(0.008)\end{array}$ & $\begin{array}{l}0.181^{* *} \\
(0.076)\end{array}$ & $\begin{array}{c}-0.261^{* * * *} \\
(0.057)\end{array}$ & $2,181,111$ & 0.51 \\
\hline 1997-2002 & $\begin{array}{l}-0.107 * * * \\
(0.026)\end{array}$ & $\begin{array}{l}0.0946 * * * \\
(0.024)\end{array}$ & $\begin{array}{l}0.478^{* * * *} \\
(0.118)\end{array}$ & $\begin{array}{c}-0.306^{* * * *} \\
(0.093)\end{array}$ & 886,983 & 0.48 \\
\hline Female & $\begin{array}{l}-0.0477 * * * \\
(0.013)\end{array}$ & $\begin{array}{l}0.0434 * * * \\
(0.012)\end{array}$ & $\begin{array}{l}0.376^{* * * *} \\
(0.093)\end{array}$ & $\begin{array}{c}-0.178 * * * \\
(0.038)\end{array}$ & $1,491,461$ & 0.49 \\
\hline Union & $\begin{array}{c}0.004 \\
(0.01)\end{array}$ & $\begin{array}{c}-0.011 \\
(0.009)\end{array}$ & $\begin{array}{c}-0.104 \\
(0.077)\end{array}$ & $\begin{array}{r}-0.075 \\
(0.073)\end{array}$ & 549,055 & 0.37 \\
\hline High school or less & $\begin{array}{l}-0.0407 * * * \\
(0.009)\end{array}$ & $\begin{array}{l}0.0319 * * * \\
(0.008)\end{array}$ & $\begin{array}{l}0.227 * * * \\
(0.081)\end{array}$ & $\begin{array}{c}-0.209 * * * \\
(0.049)\end{array}$ & $1,475,119$ & 0.44 \\
\hline College or more & $\begin{array}{c}-0.0250 * * \\
(0.011)\end{array}$ & $\begin{array}{l}0.0228 * * \\
(0.01)\end{array}$ & $\begin{array}{l}0.12 \\
(0.073)\end{array}$ & $\begin{array}{c}-0.116 \\
(0.111)\end{array}$ & $1,592,975$ & 0.44 \\
\hline Over age 40 & $\begin{array}{l}-0.0560 \text { *** } \\
(0.01)\end{array}$ & $\begin{array}{l}0.0482^{* * * *} \\
(0.009)\end{array}$ & $\begin{array}{c}0.11 \\
(0.071)\end{array}$ & $\begin{array}{l}-0.202^{* * * *} \\
(0.053)\end{array}$ & $1,262,929$ & 0.48 \\
\hline Over age 50 & $\begin{array}{l}-0.0552 * * * \\
(0.013)\end{array}$ & $\begin{array}{l}0.0487 * * * \\
(0.012)\end{array}$ & $\begin{array}{c}0.11 \\
(0.088)\end{array}$ & $\begin{array}{c}-0.287^{* * * *} \\
(0.064)\end{array}$ & 550,041 & 0.48 \\
\hline
\end{tabular}

See table 1 for sources. and five-year period and are reported in parentheses below the coefficient estimates. Wage specifications control for a worker's gender, age, race, experience, whether in a union, and imputed computer use rate by occupation and include year, education, state, industry, and two-digit occupation fixed effects. Significant at $* 10 \%, * * 5 \%, * * * 1 \%$.

income countries is associated with a $0.01 \%$ increase in wages, and this is found even for workers in the most routine occupations. In these first four columns, which rely on differences in exposure to trade or offshoring across industries, the evidence suggests that trade has no substantial negative effect on worker wages.

In columns 5 through 8 of table 2, we present results from specification (1b) where we measure exposure to trade or offshoring at the occupation level. The effects of both offshoring and trade are larger in sign and generally significant at the $5 \%$ level, in contrast to the industry-level results reported in the first four columns. In the first row of column 5 , the coefficient on low-income affiliate employment suggests that a $10 \%$ increase in employment offshored within an occupation is associated with a $0.4 \%$ wage reduction for US workers. For workers in the most routine occupations, we find that a $10 \%$ increase in low-income affiliate employment abroad is associated with a $0.7 \%$ decline in domestic wages, whereas workers in less routine occupations were largely unaffected by offshoring. Although the magnitude of the effect is small, the results are consistent with an interpretation that workers in low-income locations perform the same tasks that low-skilled workers perform in the United States and are therefore substitutes for workers in the United States.

We also find a positive effect of lagged high-incomeaffiliate employment on wages. Workers in high-income locations appear to perform tasks that are complementary to workers in the United States, and so expansion of employment in high-income countries can benefit domestic workers. These results are robust to a range of specification choices, including whether we use prices of imported and exported goods instead of quantities, and our chosen set of control variables, such as controlling for the real price of shipments by sector to account for variation in product demand. ${ }^{23}$ The results are qualitatively similar to the results presented here, and are available in the online appendix.

Our results indicate that a $10 \%$ increase in occupational exposure to import competition is associated with nearly a $3 \%$ decline in real wages for workers who perform routine tasks. While some occupations have experienced no increase in import competition (such as teachers), import competition in other occupations (such as shoe manufacturing) has increased by as much as 40 percentage points. ${ }^{24}$ For occupations with significant export activity, wages are positively linked to export growth. For these workers, a 10 percentage point increase in export share at the occupation level is associated with a 6.6 percentage point increase in wages over the sample period.

Krugman (2008) and Feenstra (2008) both hypothesize that the effects of international trade and offshoring may have increased recently relative to earlier decades. In table 3 , we split the sample into earlier and later time periods. In par-

\footnotetext{
${ }^{23}$ The results indicate that workers with price decreases in their product market have suffered the largest wage declines, with this pattern most pronounced in routine occupations. Similar to our core results, however, this effect is observed only using occupational exposure measures of import price changes. Special thanks to Lawrence Edwards for generous use of his price series data on imports. Other specifications we have tested include removing measures of TFP and controlling for price changes in the service sector using a CPI/PPI index, both of which provide results similar to those presented in table 2. Likewise, the results including the real price of shipments are similar to the results in table 2.

${ }^{24}$ See the online appendix for further information on import exposure by occupation.
} 
Table 4.-OLS Estimates of Wage Determinants Using Occupational versus Industry Exposure to OfFshoring and Trade, $1997-2002$

Dependent Variable: Log Wage

\begin{tabular}{|c|c|c|c|c|c|c|c|c|}
\hline \multirow[b]{2}{*}{ Variable } & \multicolumn{4}{|c|}{$\begin{array}{l}\text { Offshoring and Trade Measured by } \\
\text { Industry-Specific Exposure, Manufacturing Only }\end{array}$} & \multicolumn{4}{|c|}{$\begin{array}{l}\text { Offshoring and Trade Measured by } \\
\text { Occupation-Specific Exposure, All Sectors }\end{array}$} \\
\hline & $\begin{array}{c}\text { All } \\
\text { Occupations }\end{array}$ & $\begin{array}{l}\text { Most } \\
\text { Routine }\end{array}$ & $\begin{array}{l}\text { Intermediate } \\
\text { Routine }\end{array}$ & $\begin{array}{c}\text { Least } \\
\text { Rotine }\end{array}$ & $\begin{array}{c}\text { All } \\
\text { Occupations }\end{array}$ & $\begin{array}{l}\text { Most } \\
\text { Routine }\end{array}$ & $\begin{array}{l}\text { Intermediate } \\
\text { Routine }\end{array}$ & $\begin{array}{l}\text { Least } \\
\text { Rotine }\end{array}$ \\
\hline $\begin{array}{l}\text { Lagged log of low-income- } \\
\text { affiliate employment }\end{array}$ & $\begin{array}{r}-0.009 \\
(0.006)\end{array}$ & $\begin{array}{r}-0.005 \\
(0.008)\end{array}$ & $\begin{array}{l}-0.0221 * * * \\
(0.008)\end{array}$ & $\begin{array}{c}0.002 \\
(0.013)\end{array}$ & $\begin{array}{l}-0.107 * * * \\
(0.040)\end{array}$ & $\begin{array}{l}-.198 * * * \\
(0.038)\end{array}$ & $\begin{array}{l}0.147 * * * \\
(0.050)\end{array}$ & $\begin{array}{c}0.330 * \\
(0.165)\end{array}$ \\
\hline $\begin{array}{l}\text { Lagged log of high-income- } \\
\text { affiliate employment }\end{array}$ & $\begin{array}{c}-0.002 \\
(0.009)\end{array}$ & $\begin{array}{r}-0.014 \\
(0.010)\end{array}$ & $\begin{array}{c}0.004 \\
(0.013)\end{array}$ & $\begin{array}{c}0.016 \\
(0.022)\end{array}$ & $\begin{array}{l}0.0947 * * \\
(0.037)\end{array}$ & $\begin{array}{l}0.169 * * * \\
(0.035)\end{array}$ & $\begin{array}{l}-0.140 * * * \\
(0.042)\end{array}$ & $\begin{array}{c}-0.299 * * \\
(0.143)\end{array}$ \\
\hline Lagged export share & $\begin{array}{r}-0.021 \\
(0.072)\end{array}$ & $\begin{array}{c}-0.111 \\
(0.078)\end{array}$ & $\begin{array}{c}0.039 \\
(0.092)\end{array}$ & $\begin{array}{c}0.049 \\
(0.075)\end{array}$ & $\begin{array}{l}0.478 * * * \\
(0.178)\end{array}$ & $\begin{array}{l}0.999 * * * \\
(0.240)\end{array}$ & $\begin{array}{c}0.292 \\
(0.271)\end{array}$ & $\begin{array}{l}-0.808 \\
(0.948)\end{array}$ \\
\hline Lagged import penetration & $\begin{array}{c}0.119 \\
(0.073)\end{array}$ & $\begin{array}{l}0.196^{* *} \\
(0.094)\end{array}$ & $\begin{array}{l}-0.067 \\
(0.150)\end{array}$ & $\begin{array}{r}-0.094 \\
(0.176)\end{array}$ & $\begin{array}{l}-0.306 * * \\
(0.146)\end{array}$ & $\begin{array}{c}-0.437 * * \\
(0.160)\end{array}$ & $\begin{array}{l}-0.035 \\
(0.587)\end{array}$ & $\begin{array}{c}1.668 \\
(1.419)\end{array}$ \\
\hline Number of observations & 132,104 & 71,985 & 36,982 & 23,137 & 886,984 & 291,894 & 337,057 & 258,033 \\
\hline$R^{2}$ & 0.44 & 0.35 & 0.40 & 0.34 & 0.48 & 0.39 & 0.51 & 0.37 \\
\hline
\end{tabular}

See table 1 for sources. Robust standard errors are reported in parentheses below the coefficient estimates. The workers are taken from CPS samples from 1997 to 2002, with their lagged values of the independent variables taken from 1996 to 2001. The standard errors are clustered by industry and five-year period in columns $1-4$, and by occupation and five-year period in columns 5-8. The classification of occupations into routine categories is determined by the proportion of tasks that are routine in each occupation, with low being occupations with more than two-thirds, intermediate being between one-third and two-thirds, and high being occupations with less than one-third of tasks designated routine. We also control for the lagged log price of investment, lagged total factor productivity, and lagged capital-to-labor ratio among manufacturing being occupations with less than one-third of tasks designated routine. We also control for the lagged log price of investment, lagged total factor productivity, and lagged capital-to-labor ratio among manufacturing
workers. Among nonmanufacturing workers, these controls are set equal to unity. Wage specifications control for a worker's gender, age, race, experience, whether in a union, and include industry, year, education, workers. Among nonmanufacturing workers, these controls are set equal to unity. Wage specifications control for a worker's gender, age, race, experience, whether in a union, and include industry, year, education,
and state fixed effects. The occupation-specific exposure regressions also include two-digit occupation fixed effects. Controls for computer use rates are imputed by the worker's industry (columns $1-4)$ and by occupation (columns 5-8). Significant at *10\%,**5\%,***1\%.

ticular, we allow the impact of globalization to vary between 1984 and 1991, and 1992 through 2002, when our sample ends. We also explore whether the impact of globalization varied for female workers, unionized workers, across education levels, and for different age groups. The results in table 3 suggest that there is no significant association between log wages and employment in offshore locations in the early years of our sample (1984-1991, 1984-1996). However, in the later periods (1992-2002, 1997-2002), worker wages are negatively and significantly associated with increased offshore employment in low-income-affiliate locations. In the years 1997 to 2002, the coefficient estimates in the fourth row of table 3 indicate that a $10 \%$ increase in low-incomeaffiliate employment is associated with a $1 \%$ decrease in domestic wages. These negative coefficients contrast with the positive coefficients on high-income-affiliate employment. For 1997 through 2002, a 10\% increase in highincome-affiliate employment is associated with nearly a $1 \%$ increase in domestic wages.

Table 3 also reports the coefficient on lagged imports and exports, measured at the occupation level. The point estimates for occupation-specific import penetration are statistically significant across all time periods, with the coefficients ranging from -0.21 to -0.32 . These coefficients indicate that a 10 percentage point increase in import penetration is associated with a wage decline in the exposed occupation of $2 \%$ to $3 \%$. The coefficients become larger and more negative in magnitude in the later time periods. The evidence also points to a positive and significant association between export share and domestic wages, but the point estimates are positive and significant for export share only in the later part of the sample period.

In table 3, we also explore heterogeneity in our results across different demographic groups. Anecdotes in the popular press and elsewhere suggest that women, union workers, and older workers may have been disproportionately affected by international competition. If we restrict the sample to either women or union workers, there is no evidence that their wages were more negatively affected than the rest of the sample. In fact, the wages of unionized workers appear to have been relatively unaffected by export activity or import competition. However, the wages of workers without higher education and older workers do appear to have been disproportionately affected by offshoring activities, as the point estimates are larger for these groups of workers. The estimates in table 3 indicate that all of the negative and significant effects of offshore employment and import penetration were concentrated on workers with a high school education or less.

Since the results point to much stronger effects of offshore activities on domestic wages in the later part of the sample period, we reproduce table 2 for the 1997 through 2002 period in table 4 . The results confirm that for the last five years of our sample, offshoring and international trade exerted much larger effects on occupation-specific wages than the earlier years. The results also confirm that over the most recent sample period, industry-level wage effects are negligible. In columns 1 through 4, all but two of the point estimates are statistically insignificant and the magnitudes are close to 0 , indicating that offshoring or trade does not significantly affect industry-level wage premiums.

Columns 5 through 8 suggest that occupation-specific changes in offshoring and trade are associated with significant wage effects, particularly for workers in the most routine occupations. For these workers, a $10 \%$ increase in offshoring to low-income countries is associated with a $2 \%$ decrease in wages. For most workers, however, a 10 percentage point increase in high-income-affiliate employment is associated with a $1.7 \%$ increase in wages. One explanation is that workers in high-income locations perform tasks that are complementary to routine workers in the United States. 


\begin{tabular}{|c|c|c|}
\hline \multirow[b]{2}{*}{ Variable } & \multicolumn{2}{|c|}{$\begin{array}{l}\text { Offshoring and Trade Measured by } \\
\text { Occupation-Specific Exposure in } 2002\end{array}$} \\
\hline & 1984-1989 & 1997-2002 \\
\hline $\begin{array}{l}\text { Log of low-income- } \\
\quad \text { affiliate employment in } 2002\end{array}$ & $\begin{array}{c}0.015 \\
(0.055)\end{array}$ & $\begin{array}{l}-0.0862 * * \\
(0.042)\end{array}$ \\
\hline $\begin{array}{l}\text { Log of high-income- } \\
\text { affiliate employment in } 2002\end{array}$ & $\begin{array}{c}-0.014 \\
(0.050)\end{array}$ & $\begin{array}{l}0.0769^{* *} \\
(0.038)\end{array}$ \\
\hline Export share in 2002 & $\begin{array}{c}-0.079 \\
(0.248)\end{array}$ & $\begin{array}{l}0.445^{* * * *} \\
(0.157)\end{array}$ \\
\hline Import penetration in 2002 & $\begin{array}{r}-0.118 \\
(0.150)\end{array}$ & $\begin{array}{l}-0.358 * * * \\
(0.124)\end{array}$ \\
\hline $\begin{array}{l}\text { Number of observations } \\
R^{2}\end{array}$ & $\begin{array}{c}1,036,302 \\
0.53\end{array}$ & $\begin{array}{c}886,958 \\
0.48\end{array}$ \\
\hline
\end{tabular}

See table 1 for sources. Robust standard errors are clustered at the occupation level and reported in parentheses below the coefficient estimates. The independent variables reported for the globalization exposure are taken from the worker's occupational exposure in 2002. The sample in each column includes workers in all sectors for the listed period. The regressions include the same controls that are included in the regressions using occupational exposure in table 2 . Significant at $* 10 \%, * * 5 \%, * * * 1 \%$.

A $1 \%$ increase in export shares is associated with a $1 \%$ increase in wages, while a $1 \%$ increase in import penetration is associated with a $-0.44 \%$ decline in wages. The effects of these globalization measures are generally small in magnitude and insignificant for individuals who work in the occupations with the least routine content.

While we control for a number of observables, there are other shocks that might be difficult to control for and could affect workers in routine occupations. To verify that our results are not driven by secular trends in which wage changes, globalization, and technological change are all moving together over time, we present a falsification exercise in table 5. In particular, we regress current period wage changes for 1984 through 1989 on future globalization shocks for 2002. Our future globalization shocks are the logs of low- and high-income-affiliate employment in 2002, as well as export shares and import penetration in 2002. If the analysis is driven by spurious trends, the coefficient on 2002 measures of globalization should be significant in explaining wages for the 1984 through 1989 period. Table 5 shows that 2002 measures of globalization do not significantly affect wages in the earlier period. In contrast, 2002 measures of globalization do significantly affect wages from 1997 through 2002. For example, our offshoring measure to low-income countries is significantly negatively correlated with wage changes among workers during this later period. This is new evidence that our results are not being driven simply by a spurious correlation between offshoring and domestic wage changes. ${ }^{25}$

\footnotetext{
${ }^{25}$ It is worth discussing alternative possibilities that could undermine our interpretations of our findings. For example, it may be that even if the United States engaged in autarky in this later period, domestic workers would have been replaced by machines, thereby implicating offshoring when the workers' decline was inevitable. This possibility naturally cannot be evaluated in our data. Also, if our technology control variables are measured with error, it may be that the wage declines we observe are a by-product of the substitutability between these workers and capital. However, we would argue that the strong correlation between the timing of increased offshore employment and declining domestic wages seems unlikely to be fully explained by stories of this nature.
}

\section{B. Offshoring, Trade, and the Reallocation of Labor across Sectors}

In this section, we try to identify mechanisms for the differences between industry-level and occupation-level exposure to offshoring and trade. We begin by analyzing the relationship between offshoring and domestic manufacturing employment. We then examine the wage consequences of switching industries, sectors, and occupations using a panel of CPS workers who are followed for more than one period.

In table 6 , we present an analysis of employment trends in manufacturing in response to offshoring. Our unit of analysis is each Education $\times$ Industry $\times$ Year cell. There are 5 education categories for workers, 67 manufacturing industries, and 19 years of data (1984-2002). In column 1, we present pooled results for all industries, and in the remaining columns we split industries by the fraction of an industry's workforce performing routine tasks. When we pool across all task types, the results in column 1 indicate that the impact of offshoring depends on whether affiliate employment is located in highor low-income countries. A $1 \%$ increase in employment in low-income countries reduces domestic employment by $0.02 \%$, while a $1 \%$ increase in employment in high-income countries increases domestic employment by $0.07 \%$. Breaking the results down according to how routine the workforce is, we see that the negative effects of offshoring to lowincome countries are largest for workers in the most routine industries. The point estimate in column 2 , at -0.041 , suggests that a $1 \%$ increase in affiliate employment in lowincome locations is associated with a $0.041 \%$ reduction in employment of workers in the most routine occupations.

In contrast, greater offshoring to high-wage countries is associated with a significant increase in employment in the United States. Across all workers, the evidence suggests that a $1 \%$ increase in affiliate employment in high-income locations is associated with a $.074 \%$ increase in employment at home. For routine workers, the impact is more positive, with a 1 percentage point increase in offshore employment in high-income countries associated with a .15\% to $.19 \%$ increase in U.S. employment. This evidence suggests that offshore employment in high-income locations is complementary with employment at home. The evidence presented in table 6 is consistent with Harrison and McMillan (2011), who use firm-level BEA data to show that domestic employment of U.S. multinationals is complementary with their employment in high-income locations but that increasing employment of U.S. firms in low-income locations substitutes for employment in the United States. ${ }^{26}$

\footnotetext{
${ }^{26}$ Our online appendix includes a rich set of robustness checks for these results. Among these are a set of results based on instrumental variables estimation where we instrument for trade and offshoring using the variables that capture changes over time in the cost of trade and offshoring. The instruments are Internet access, telephone connections including cell phone use, and the industry share of routine jobs. The results confirm the negative relationship between offshoring to low-income countries, import penetration, and manufacturing employment.
} 
Table 6.-OLS Estimates of Employment Determinants in Manufacturing, 1984-2002

Dependent Variable: Log U.S. Manufacturing Sector Employment

\begin{tabular}{|c|c|c|c|c|}
\hline Variable & All & Most Routine & Intermediate Routine & Least Routine \\
\hline Lagged log of low-income-affiliate employment & $\begin{array}{c}-0.0202 * \\
(0.011)\end{array}$ & $\begin{array}{l}-0.0413 * * \\
(0.02)\end{array}$ & $\begin{array}{c}0.007 \\
(0.021)\end{array}$ & $\begin{array}{r}-0.046 \\
(0.044)\end{array}$ \\
\hline Lagged log of high-income-affiliate employment & $\begin{array}{l}0.0736^{* *} \\
(0.031)\end{array}$ & $\begin{array}{l}0.148 * * \\
(0.064)\end{array}$ & $\begin{array}{l}0.192 * * * \\
(0.05)\end{array}$ & $\begin{array}{c}0.013 \\
(0.132)\end{array}$ \\
\hline Lagged log of price of investment & $\begin{array}{c}0.124 \\
(0.093)\end{array}$ & $\begin{array}{l}0.489 * * * \\
(0.16)\end{array}$ & $\begin{array}{c}0.197 \\
(0.209)\end{array}$ & $\begin{array}{c}-0.094 \\
(0.52)\end{array}$ \\
\hline Lagged total factor productivity level & $\begin{array}{c}0.000 \\
(0.017)\end{array}$ & $\begin{array}{l}0.0680 * * \\
(0.033)\end{array}$ & $\begin{array}{l}-0.0612 * * * \\
(0.023)\end{array}$ & $\begin{array}{c}0.602 \\
(0.632)\end{array}$ \\
\hline Lagged export share & $\begin{array}{r}-0.393 \\
(0.258)\end{array}$ & $\begin{array}{c}-0.555 \\
(0.666)\end{array}$ & $\begin{array}{c}0.112 \\
(0.321)\end{array}$ & $\begin{array}{r}-0.216 \\
(1.326)\end{array}$ \\
\hline Lagged import penetration & $\begin{array}{c}-0.614^{*} \\
(0.356)\end{array}$ & $\begin{array}{c}-0.313 \\
(0.682)\end{array}$ & $\begin{array}{c}-0.084 \\
(0.338)\end{array}$ & $\begin{array}{l}0.133 \\
(1.547)\end{array}$ \\
\hline Lagged capital to labor ratio & $\begin{array}{l}-0.867 * * \\
(0.373)\end{array}$ & $\begin{array}{r}-0.983 \\
(1.043)\end{array}$ & $\begin{array}{l}-1.108 * * \\
(0.436)\end{array}$ & $\begin{array}{r}-0.338 \\
(1.504)\end{array}$ \\
\hline Lagged computer use rates by industry & $\begin{array}{c}-0.036 \\
(0.147)\end{array}$ & $\begin{array}{c}0.049 \\
(0.269)\end{array}$ & $\begin{array}{l}-0.122 \\
(0.207)\end{array}$ & $\begin{array}{r}-0.700 \\
(0.482)\end{array}$ \\
\hline $\begin{array}{l}\text { Number of observations } \\
R^{2}\end{array}$ & $\begin{array}{c}6,399 \\
0.86\end{array}$ & $\begin{array}{c}1,662 \\
0.78\end{array}$ & $\begin{array}{c}4,248 \\
0.55\end{array}$ & $\begin{array}{l}489 \\
0.65\end{array}$ \\
\hline
\end{tabular}

See table 1 for sources. Robust standard errors are reported in parentheses below the coefficient estimates and are clustered by industry. All models include year and industry fixed effects. Low-income-affiliate employment is defined according to the World Bank income categories. The sample size corresponds to five education groupings $\times 19$ years $\times 67$ industries, less missing values. The results shown in columns $2-4$ employment is defined according to the World Bank income categories. The sample size corresponds to five education groupings $\times 19$ years $\times 67$ industries, less missing values. The results shown in columns $2-4$
are (for column 2) industry and year combinations where more than two-thirds of the tasks are routine, (for column 3 ) cells where between one-third and two-thirds of tasks are routine, and (for column 4) cells where are (for column 2 ) industry and year combinations where more than two-thirds of

The coefficients on offshoring in table 6 are significant but small in magnitude and suggest both substitution (in low-income countries) and complementarity (in highincome locations). In contrast, the coefficients are large and negative but imprecisely estimated for both import penetration and export activity. For the pooled sample, a 1 percentage point increase in import penetration reduces U.S. manufacturing employment by $0.61 \%$. While it is not surprising that the coefficient on import competition is negative, the negative coefficient on sectoral export shares is less intuitive and deserves explanation. The negative coefficients may indicate that export growth was labor saving for workers with less than a college degree, which is sensible if a significant degree of offshoring takes place through exports for further processing. Likewise, the negative and significant coefficient on total factor productivity suggests that productivity growth has been labor saving for most educational categories. ${ }^{27}$ Productivity growth in manufacturing has been achieved in conjunction with falling employment.

The results in table 6 suggest that productivity growth, export growth, and import competition have been associated with (sometimes significant) declines in domestic manufacturing employment and that the effects of offshoring have been smaller in magnitude and mixed in sign. These results are important insofar as they suggest a fluid labor market where changes in other factor prices and global competition lead to employment reallocation. Furthermore, these results provide an explanation for our finding in table 2 that the within-industry wage effects of trade and offshoring are smaller than the within-occupation effects. If trade and offshoring lead some workers to shift sectors (in

\footnotetext{
${ }^{27}$ The results in table 6 are robust to excluding total factor productivity as a control variable.
}

particular, to exit high-wage jobs in manufacturing), then it is possible that the wages of those who retain their jobs or find new jobs in the same industry are not significantly affected by offshoring, whereas those who shift sectors or occupations are more negatively affected. ${ }^{28}$ We examine this conjecture in table 7 .

To explore the impact of switching out of manufacturing on wage outcomes, we construct a sample of manufacturing workers observed in CPS samples in consecutive years between 1983 and 2002. We regress the change in log wages between period $t$ and $t+1$ for a given worker on an indicator for switching occupation, including a rich set of controls for the worker's age, sex, education, race, union status in the first period, and industry in the first period. If switching occupation is costly, it may explain why the negative impact on wages is so large in our main results. As shown in table 7, the data indicate that trade-induced occupation switching does indeed have serious negative wage consequences for workers. Using our matched sample of CPS ORG workers who are observed in consecutive years, we compare the wage difference in period $t$ and $t+1$ for workers who switch occupations versus those who do not. In panel A, we examine workers who switch across three-digit occupational categories. In column 1, we examine the wage impact of all occupations switched and find that the impact is negligible; an occupation change is associated with a $0.54 \%$ increase in wages. One possible explanation for this result is that some

\footnotetext{
${ }^{28}$ In results available in the online appendix, we directly assess the wage consequences among those who switch industries within manufacturing. We find that (1) switching within manufacturing has mild wage consequences, (2) but leaving manufacturing has a more negative impact, and (3) leaving manufacturing is particularly costly for workers who switch occupations. These were not included in the main text due to space considerations.
} 
Table 7.- Wage Impact of Switching Occupations Using CPS Workers in Repeated Samples, 1984-2002

\begin{tabular}{|c|c|c|c|}
\hline & OLS & First Stage & Two-Stage Least Squares \\
\hline & Log Wage Difference & Switched Occupation & Log Wage Difference \\
\hline & $(1)$ & (2) & (3) \\
\hline \multicolumn{4}{|c|}{ A: Defining an occupation switch by switching three-digit occupation } \\
\hline Switched Occupations between $T$ and $T+1$ & $\begin{array}{r}0.0054 \\
(0.005)\end{array}$ & & $\begin{array}{l}-0.121^{* *} \\
(0.051)\end{array}$ \\
\hline Interoccupation Wage Differential Gap Term ${ }^{a}$ & $\begin{array}{c}0.281 \\
(0.223)\end{array}$ & & $\begin{array}{c}0.190 \\
(0.252)\end{array}$ \\
\hline Tradable Occupation ( 1 = yes $)$ & & $\begin{array}{l}0.0942 * * * \\
(0.022)\end{array}$ & \\
\hline & 851,467 & 851,467 & 851,467 \\
\hline$F$-test of Instrument & & 18.91 & \\
\hline \multicolumn{4}{|c|}{ B: Defining an occupation switch by switching one-digit occupation } \\
\hline Switched occupations Between $T$ and $T+1$ & $\begin{array}{c}-0.00153 \\
(0.001)\end{array}$ & & $\begin{array}{l}-0.172 * * * \\
(0.059)\end{array}$ \\
\hline Interoccupation wage Differential gap term & $\begin{array}{c}-0.0506 \\
(0.076)\end{array}$ & & $\begin{array}{c}-0.0594 \\
(0.131)\end{array}$ \\
\hline Tradable occupation $(1$ = yes $)$ & & $\begin{array}{l}0.0693 * * * \\
(0.020)\end{array}$ & \\
\hline $\begin{array}{l}\text { Number of observations } \\
F \text {-test of instrument }\end{array}$ & 851,467 & $\begin{array}{c}851,467 \\
11.66\end{array}$ & 851,467 \\
\hline $\begin{array}{l}\text { Sample is composed of CPS MORG workers observed in two consecutive s } \\
\text { models include year, state, and education level fixed effects. Other demograp } \\
\text { low-income countries (as described in table 2) is above the median level amon } \\
\text { ional switches. In panel A, we define an occupation switch by the worker rep } \\
\text { aThe Interoccupation Wage Differential Gap term is calculated by regre } \\
\text { switch occupations between periods. The difference in means of these term } \\
* * 5 \%, * * * 1 \% \text {. }\end{array}$ & $\begin{array}{l}\text { bust standard errors reported in } \\
\text { s are age, sex, nonwhite, and un } \\
\text { turing workers in the sample. Th } \\
\text { ferent three-digit occupation. In } \\
\text { Norkers' log wage on observab } \\
\text { led in our regressions to contro }\end{array}$ & $\begin{array}{l}\text { below coefficient estimates. S } \\
\text { the first period. An occupatio } \\
\text { generate a binary variable for } \\
\text { occupation switch is defined by } \\
\text { ristics and a set of occupation } \\
\text { ial selection on unobservables }\end{array}$ & $\begin{array}{l}\text { ors are clustered by three-digit occu } \\
\text { las tradable if the occupational exp } \\
\text { in the sample and is the instrument } f \\
\text { eporting a different one-digit occup } \\
\text { among all workers and among wo } \\
\text { who switch occupations. Significan }\end{array}$ \\
\hline
\end{tabular}

switches are upward (as measured by average occupational wages), and others are downward, leaving a mixed result for all switches. This hypothesis is put forward in Trefler and Liu (2011), who find evidence that switches of both types are common in response to trade.

In order to examine the impact of trade-induced occupational switching on wage outcomes, we consider a system of equations for estimation. In our first stage, we examine the impact of occupational exposure on the probability of switching occupations between periods. We create a dichotomous measure of our instrument. All workers who are employed in occupations above the median level of offshore exposure from low-income countries are considered "tradable." The results, presented in column 2, indicate that being in a tradable occupation is associated with a 9.4 percentage point increase in the probability of switching occupations between periods. In our second stage, we examine the relationship between switching occupations and wage declines when this switch is induced by trade. We find that trade-induced occupation switches are associated with a $12.1 \%$ decline in wages between periods. This result is consistent with our earlier results highlighting negative consequences of globalization on wages of workers who perform tasks that can be performed in low-income countries. In panel B, we perform a similar analysis but use a broader classification of occupation. If a narrower definition of occupation implies that a worker is more likely to be performing a similar task, these switches will presumably have less important wage consequences. Consistent with this hypothesis, the results in panel 2 indicate that trade is less likely to induce a switch to a new two-digit occupation (6.9 percentage points), but upon switching, the negative wage consequences are even more severe: a trade-induced occupational switch across two-digit categories is associated with a $17.2 \%$ decline in wages. These results suggest that switching occupations is very costly to workers and provides support for our main results, suggesting that occupational exposure to competition from trade or offshoring has more significant consequences than industry exposure.

One possibility is that workers who switch occupations in a downward manner are less productive in unobserved dimensions of worker quality. Weaker workers may sort into less demanding occupations, and this may not be captured by the human capital measures available in the CPS (e.g., education). While we are unable to observe variation in the quality of workers on unobserved dimensions, we attempt to address this possibility by adding a control to the wage equation, which is the difference between the interoccupation wage differential for all workers in a sector and the interoccupation wage differential for workers who leave that sector in the following period. If workers who remain and those who leave a sector are similar, then this difference should be close to 0 , and adding it as an additional control should have no impact on our estimate. The negative impact of switching occupations on wages is unaffected by the inclusion of the interoccupation wage differential term (see also Trefler \& Liu, 2011, for an application to services). Our results are suggestive that in manufacturing, worker heterogeneity does not explain the significant decline in wages of workers who leave their occupation due to trade or offshoring pressures.

Our results are consistent with work by Kambourov and Manovskii (2008, 2009a, 2009b), who find large wage declines among workers who switch occupations; this evidence suggests an important role for occupation-specific 
human capital in a worker's wage profile. Kambourov and Manovskii (2008, 2009a, 2009b) also argue that occupation switching may be an important cause of the increase in U.S. wage inequality, as younger workers are missing out on the benefits to occupational tenure enjoyed by workers in previous decades. Insofar as this is partly driven by competition from overseas, this highlights another mechanism by which offshoring may be responsible for declining U.S. wages and increasing wage inequality.

\section{Conclusion}

This paper reexamines the impact of trade and offshoring, two primary measures of globalization, on U.S. workers. Using CPS data, which we merge with data on exports, imports, and BEA data on offshoring, we make three main contributions. First, we draw a distinction between the impact of globalization on industrial wage differentials and on occupation wage differentials. Globalization has had small or insignificant effects on industry wage differentials but significant effects on occupation wage differentials. These results are consistent with recent empirical work demonstrating the importance of occupational tenure and downplaying the importance of tenure within a particular industry in determining a worker's wage.

Second, we extend previous analyses that focused exclusively on manufacturing sector workers to explore the impact of trade and offshoring on all workers. Third, we use a two-stage approach to show that one important avenue through which globalization affects wages is by pushing workers out of the manufacturing sector to take lower-paying jobs elsewhere. Using a CPS panel of workers and the exposure of an occupation to trade as an instrument for whether a worker switched occupations, we find that occupation switching due to trade led to real wage losses of 12 to 17 percentage points between 1983 and 2002. The results are robust to the inclusion of a term from Trefler and Lui (2011) that captures the possibility that the least able workers are most likely to switch into lower-paying occupations.

Our results provide new evidence that the negative consequences of trade on workers are mediated through a reallocation of labor across sectors and into different occupations. While older models of trade posited that workers could move in a costless manner to new jobs in the face of pressure from foreign labor, we identify large and significant wage declines among workers who leave manufacturing; the wage decline is particularly pronounced for those who switch occupations. These results are consistent with new trade models that introduce frictions into the labor reallocation process, such as Cosar (2010) and Artuc et al. (2010). Our evidence is consistent with greater frictions in moving across occupations rather than across industries.

We also explored how the impact of globalization on wages has changed over time. Our different measures of globalization have no significant impact on wages during the first half of our sample. While our sample extends from 1984 to 2002, both offshoring and trade exert significant effects on wages only in the second half of this period. The effects of these globalization measures are confined to individuals who work in routine occupations, indicating that much of the brunt of globalization is borne by individuals who perform tasks that are easily copied by workers elsewhere.

\section{REFERENCES}

Artuç, Erhan, Shubham Chaudhuri, and John McLaren, "Trade Shocks and Labor Adjustment: A Structural Empirical Approach," American Economic Review 100 (2010), 1008-1045.

Autor, David H., Lawrence F. Katz, and Melissa S. Kearney, "Trends in US Wage Inequality: Revising the Revisionists," this REVIEW 90 (2008), 300-323.

Autor, David H., Lawrence F. Katz, and Alan B. Krueger, "Computing Inequality: Have Computers Changed the Labor Market?" Quarterly Journal of Economics 113 (1998), 1169-1213.

Autor, David H., Frank Levy, and Richard Murnane, "The Skill Content of Recent Technological Change: An Empirical Exploration," Quarterly Journal of Economics 118 (2003), 12791334.

Autor, David, David Dorn, and Gordon H. Hanson, "The China Syndrome: Local Labor Market Impacts of Import Competition in the United States," University of California, San Diego, unpublished manuscript (2012).

Bernard, Andrew, J. Bradford Jensen, and Peter Schott, "Survival of the Best Fit: Exposure to Low-Wage Countries and the (Uneven) Growth of US Manufacturing," Journal of International Economics 68 (2006), 219-237.

Cosar, A. Kerem, "Adjusting to Trade Liberalization: Reallocation and Labor Market Policies," University of Chicago, Booth School of Business, unpublished manuscript (2010).

Desai, Mihir, C. Fritz Foley, and James R. Hines, "Domestic Effects of the Foreign Activities of US Multinationals," American Economic Journal: Economic Policy 1 (2009), 181-203.

Freeman, Richard, “Are Your Wages Set in Beijing?" Journal of Economic Perspectives 9 (1995), 15-32.

Feenstra, Robert C., "Offshoring in the Global Economy," Ohlin Lecture at the Stockholm School of Economics, September 17-18, 2008.

Feenstra, Robert C., and Gordon H. Hanson, “The Impact of Outsourcing and High-Technology Capital on Wages: Estimates for the US, 1972-1990," Quarterly Journal of Economics 114 (1992), 907940.

Grossman, Gene M., and Esteban Rossi-Hansberg, "Trading Tasks: A Simple Theory of Offshoring," American Economic Review 98 (2008), 1978-1997.

Harrison, Ann, and Margaret McMillan, "Offshoring Jobs? Multinationals and U.S. Manufacturing Emploment," this REVIEW 93(3), $857-875$.

Hummels, David, Rasmus Jørgensen, Jakob R. Munch, and Chong Xiang, "The Wage Effects of Offshoring: Evidence from Danish Matched Worker-Firm Data," NBER working paper 17496 (2011).

Jensen, J. Bradford, and Lori G. Kletzer, "Tradable Services: Understanding the Scope and Impact of Services Offshoring," Institute for International Economics working paper WP 05-9 (2005).

Kambourov, Gueorgui, and Iourii Manovskii, "Rising Occupational and Industry Mobility in the United States: 1968-97," International Economic Review 49 (2008), 41-79.

"Occupational Specificity of Human Capital," International Economic Review 50 (2009a), 63-115.

"Occupational Mobility and Wage Inequality," Review of Economic Studies 76 (2009b), 731-759.

Katz, Lawrence F., and Lawrence H. Summers, "Industry Rents: Evidence and Implications," Brookings Papers on Economic Activity, Microeconomics 1989, 209-290.

Krueger, Alan B., and Lawrence H. Summers, "Efficiency Wages and the Inter-Industry Wage Structure," Econometrica 56 (1988), 259293. 
Krugman, Paul, "Trade and Wages, Reconsidered," Brookings Papers on Economic Activity, Spring (2008), 103-154.

Lemieux, T, "Increasing Residual Wage Inequality: Composition Effects, Noisy Data, or Rising Demand for Skill?" American Economic Review 96 (3) (2006), 461-498.
Menezes-Filho, Naércio, and Marc-Andreas Muendler, "Labor Reallocation in Response to Trade Reform,” NBER working paper 17372 (2011).

Trefler, Daniel, and Runjuan Liu, "A Sorted Tale of Globalization: White Collar Jobs and the Rise of Service Offshoring," NBER working paper 17559 (2011). 